\title{
INCIDENCE OF MESOPHILIC AEROMONAS IN FROZEN BEEF, POULTRY AND FISH
}

\author{
Y. El. A. Mahmoud and N. Yehia \\ Fac. Vet. Med. Tanta Univ., - Kafr-El Shiekh Branch
}

ABSTRACT

A total of 90 random samples from frozen beef,poultry and fish (30 of each) were collected from different supermarkets at different localities in Kafr-El Shiekh Governorate. The samples were examined for detection of Aeromonas species using two different selective media.Results obtained on Ampicillin Dextrine Agar revealed that the log mean of Aeromonas count was 3.39, 4.23 and 5.10 in beef,poultry and fish samples, respectively, while on modified Bile Irgasan Brillient Green Agar the log mean count was 2.15,2.10 and 3.38 in beef,poultry and fish samples, respectively. Aeromonas Hydrophila, (46.67\%), (50\%) and (60\%), respectively, in beef, poultry and fish followed by Aeromonas Sobria (30.0\%), (33.3\%), (23.33\%), (16.7\%) and (16.7\%) and (23.3\%), respectively, in beef,poultry and fish.The lower incidences were for Aeromonas Caviae, in beef,poultry and fish samples. The obtained results and the public health significance for these organisms were discussed.

\section{INTRODUCTION}

Members of the genus Aeromonas are typically aquatic bacteria and sometimes pathogenic for fish and cold blooded vertebrates (Hobbs and Diane,1993). Aeromonas grow readilyatrefrigeration temperature and were isolated from various foods of animal origin like, sea foods, poultry, beef, pork,lambs and raw milk(Kumar et.al.,2000).Production of enterotoxins by the members of the genus Aeromonas were involved in sporadic human gastroenteritis outbreaks, although there were no fully confirmed food borne outbreaks have been described in the scientific literatures (Bonnic and Okrend, 1998). (Hobbs and Diane, 1993) reported that there are three types of human illness associated with the gastrointestinal infections due toAeromonas spp.which are small intestinal diarrhoea,classical dysentery involving the large intestine and combination with both. They also reported that the organism may be involved in traveler's diarrhoea.Moreover,Aer- 
omonas species were isolated from stools of adults and children suffered from diarrhoea and the cultures taken revealed enterotoxin production (Schmitt,et.al.1998;Merino et.al.1995 and Namdari and Bottone,1990). Long term studies on diarrhoeaic patients,(Burke et.al. 1983) found that Aeromonas Hydrophila,Aeromonas Caviae and Aeromonas Sobria were the main species isolated from these cases.In addition,Burke et.al.,(1984) isolated heat stable cytotoxic and enterotoxic active strains from patient diarrhoeaic stools consumed fish products and other marine products. Aeromonas bacteriaemia after bowel infection was recorded by Huys et.al., (1995) in immuonocompermised hosts with underlying malignancy as leuckaemia and fatality rate of $61 \%$.Skin lesions as ecthymogangarenosium, associated with septecamia, aggressive infection does not respond to treatment with antibiotic and incomplete abortion may also occur which require massive doses of antibiotic and extreme surgical debridement $($ Hobbs and Diane, 1993). Therefore this study was planned to elucidate the contamination of frozen beef, poultry and fish meat, with Aeromonas spp and to obtain some data about the possible risks for consumers .

\section{MATERIALS AND METHODS}

A grand total90 random samples of frozen beef,poultry and fish (30 of each) were collected from different supermarkets at different localities in Kafr-Elshiekh Governorate. The samples were collected under good hygienic conditions and transferred in an ice box to the laboratory with minimum time of delay. The collected samples were examined quantitatively for incidence of Aeromonas species according toSchmitt et.al.,(1998) and Neyts et.al.,(2000).

\section{Quantitative examination:}

30 grams of each sample were according to polumbo et.al, (1985) aseptically transferred to a sterile stomacher bag contains $270 \mathrm{ml}$ of peptone salt solution for preparing the original dilution $(10-1)$. Then 10 fold serial dilution were prepared.Two selective cultural media were used for enumeration,the first Ampicillin Dextrin Agar (ADA) and the second modified Bile Irgasan Brillient Green Agar(mBIBGA)each of 0-1 ml from the original and other serial dilutions were spread over the surface of each solidified media using sterile glass spreader(Polumbo et.al.,1985). Both media were 
incubated at $30^{5} \mathrm{C}$ for 24 hours. After incubation typical colonies were enumerated and three typical colonies were transferred onto Tryptic Soy Agar slants and incubated at $30^{5} \mathrm{C}$ for 24 hours . The cultures identified by oxidase, catalase test, Gram stain reaction, biochemical characteristics on mannitole, arginine, ornithine, gas from glucose, csculin hydrolysis and reaction on triple sugar iron agar .

\section{RESULTS}

Table (1): The log mean value of Aeromonas count using two selective media from the examined samples $n=90$

\begin{tabular}{|c|c|c|c|c|c|c|c|}
\hline \multirow[t]{2}{*}{ Samples } & \multirow{2}{*}{$\begin{array}{c}\text { No. of } \\
\text { the v + } \\
\text { samples }\end{array}$} & \multicolumn{3}{|c|}{$\begin{array}{l}\text { Ampicillin Dextrine } \\
\text { Agar } \\
\end{array}$} & \multicolumn{3}{|c|}{$\begin{array}{c}\text { Modified Bile Irgasan } \\
\text { Brillient Green Agar }\end{array}$} \\
\hline & & Max. & Min. & Mean & Max. & Min. & Mean \\
\hline Frozen meat & 30 & 3.69 & 2.23 & 3.39 & 2.43 & 1.00 & 2.15 \\
\hline Frozen poultry & 30 & 4.53 & 2.18 & 4.23 & 2.34 & 1.25 & 2.10 \\
\hline Frozen fish & 30 & 5.38 & 3.46 & 5.10 & 2.66 & 1.40 & 2.38 \\
\hline
\end{tabular}

Table (2): Incidence of Aeromonas species isolated from frozen beef, poultry and fish $\mathrm{n}=90$

\begin{tabular}{|c|c|c|c|c|c|c|}
\hline \multirow{2}{*}{ Samples } & \multicolumn{2}{|c|}{$\begin{array}{c}\text { Aeromonas } \\
\text { hydrophphilla }\end{array}$} & \multicolumn{2}{|c|}{$\begin{array}{c}\text { Aeromonas } \\
\text { Sobria }\end{array}$} & \multicolumn{2}{|c|}{$\begin{array}{l}\text { Aeromonas } \\
\text { Caviae }\end{array}$} \\
\hline & No. & $\%$ & No. & $\%$ & No & $\%$ \\
\hline Frozen Beef & 14 & 46.67 & 9 & 30.0 & $\overline{7}$ & 23.33 \\
\hline Frozen Poultry & 15 & 50.0 & 10 & 33.3 & 5 & 16.7 \\
\hline Frozen Fish & 18 & 60 & 7 & 23.3 & 5 & 16.7 \\
\hline
\end{tabular}

\section{RESULTS \& DISCUSSION}

Table (1)Reveales that the log mean values of Aeromonas in frozen beef, poultry and fish samples on Ampicillin Dextrine Agar media ranged from 3.69 to 2.23 with a mean value $3.39 ; 4.53$ to 2.18 with a mean value of 4.23 and from5.38to 3.46with a mean value of 5.10, respectively. While the log mean values of Aeromonas counts on modified Bile Irgason Brillient Green Agar were ranged from 2.43 to 1.00 with a mean value 2.15; 2.34 to 1.25 with a mean value of 2.10 ; and from 2.66 to 1.40 with a mean value of 2.38 , respectively. 
The obtained results reveale that Dextrine Agar medium was more selective and detected more Aeromonas positive samples than the mBIBGA that which antagonize the results obtained by Neyts,(1995). The fish samples showed high Aeromonas count than poultry and beef samples and this prove that theAeromonas spp.Is more aquatic inhabitant and the seafoodis considered as the main source forAeromonas bacteria and the beef and poultry were contaminated from the surrounding environment(Merino et.al., 1995 and Okrend et.al.1987). Nearly similar results were reported by (Gobate and Jemmi,1993, Gobate and Jemmi,1995, Bonnic and Okrend,1998 and Kumar et.al., 000). Concerning the incidence of Aeromonas hydrophila group, it was noticed that higher incidence $(60 \%)$ was recorded with fish followed by poultry (50\%) and beef $(46.67 \%)$ on the other hand,Aeromonas Sobria was higher in poultry(33.3\%) than beef (30.0\%) and fish (23.3\%), (Table2). Moreover, Aeromonas caviae was higher(23.33\%).in beef than poultry (16.7\% for each). Nearly similar incidence results of Aeromonas hydrophila group were reported by(Buchanan and Palumbo,1985, Gobat and Jemmi,1993, Gobat and Jemmi,1995,(Schmitt et.al.,1998 and Neyts et.al.,2000). The results of this work indicated that Aeromonads are present in the examined samples and the use of more than one media gave best results which supported by what they said by Neyts et.al.,(2000).

\section{REFERENCES}

- Bonnic, R.A. and Okrend, A.J.G.(1998): Isolation and Identification of Aer-omonas species from meat poultry products USDA/FSIS, Microbiology lab-oratory Guide book 3rd Edition Chapter 7.

- Burke, 70; Gracey, M; Robinson, J.; Peck, D.; Beaman, J.and Bunde,II,C. (1983): Microbiology of childhood gastroenteritis: aeromonas species and other infective agents. J. Infect. Dis., 148:6874.

- Burke, V.; Robison, J.; cooper, M.; Bea man, J.; Partridge, K.; Peterson,D.and Gracey,M.(1984): Biotyping and virulence factors in clinical and environm-ental isolates of aeromonas species.Appl. Environ.Microbiol.47:1146-1149.

- Buchanan,R.L.and Palumbo,S.A(1985):Aeromonas hydrophila and Aerom-onas Sobriaas potential food poisoning species:a review.J. Food softy 7:15-29.

$\overline{\text { Kafr El-Sheikh Vet. Med. J. Vol. } 1 \text { No. } 2 \text { (2003) }}$ 
- Gobate, P.F. and Jemmi, T. (1993): Distribution of masnnili॰ aeromonas species in raw and ready to eat fish and $r$ Switzerland. Int. J. Food Microbiol. 20 (2): 117 - 12(.

- Gobate, P.F. and Jemmi, T. (1995): comparison of seven selective media for the isolation of mesophilic aeromonas species in fish and meat.Int. J. Food Microbiol.24 (3): 375-384.

- Hobbs, B.C. and Diane, R. (1993): Food poisoning and Food Hygiene. Sixth Edition, British library cataloguing Data publication.

- Huys, G.; Kersters, I.; Vancanneyt, M.; Coopman, R.; Janssen, P. and Kersters, K.(1995):Diversity of aeromonas species in Flemish drinking water production plants as determined by gas liquid chromatographic analysis of cellular fatty acid methyl esters (FAMEs). Journal of Applied Bacteriology, 78:445-455.

- Kumar, A.; Bachhil, V.N.; Bhilegaonakar, K.N. and Agarwal, R.K. (2000): Occurrence of enterotoxigenic aeromonas species in foods.J. Commun.Dis32 (3) :169-174.

- Merino,S.;Rubires,X;Knochel,S.and Thomas, J.(1995):Emerging pathogens: aeromonas species . International Journal of Food Microbiol, 28: 157-168.

- Namdari, H., and Botton, E. J. (1990): Cytotxinand enterotoxin production as factors delinearting enteroparopathogenicity of Aeromonas Caviae.J.Clin. Microbiol. 28: 1796-1798.

- Neyts, k.; Huys, G.; Uyttendaele, M.; Swings, J. and Debevere, J. (2000): Incidence and identification of mesophilic Aeromonas species isolated from retail foods in Belgium. APPL. Microbiol. 31 (5): 359-363.

- Okrend,A.J.G.;Rose,B.E.and Bennett,B. (1987): incidence and toxigenicity of aeromonas species in retail poultry, Beef and Pork. J. Food Protect. 50 (6): 509-513.

- Palumbo, S.A; Maxino, F.; Williams, A-C. ; Buchanan, R. L. and Thayer,D. W. (1985): Starch ampicillin agar for the quantitative

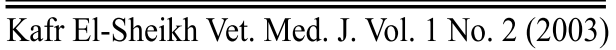


detection of Aeromonas hydrophila - AppL. Environ. Microbiol. 50 (4): 1027-1030.

- Schmitt,M.; Binkingombe,C.;Gobat,P.F. and Jemmi, T. (1998): Mesophilic Aeromonas species in raw and ready to eat fish and meat products in Switze-rland Development and high lights of a

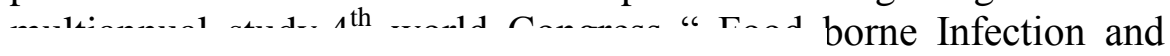
. vol II page 958.

$$
\text { مدى تو اجد ميكروبات الأبروموناس فى لحوم الأبقار و الدو اجن }
$$

$$
\text { د. . يحيى السيد على محمود - د ـ نادر يحيى مصطقى }
$$

تم جمع 90 عينة من لحوم الأبقار والدواجن والأسماك المجمدة (30 من كل نوع) من أسواق

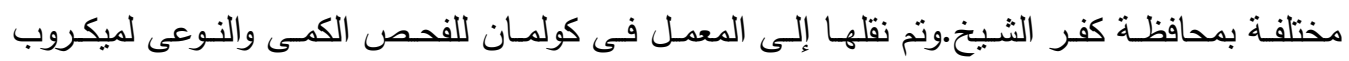
الأيرومونـاس أوضـحت نتائج الفحص الكسى أن المتوسط اللوغـاريتمى للميكروب فى عي عينات اللحوم والدواجن والأسماك 3.39 و 4.23 و 5.10 على التزتيب باستخدام الأمبسيللين دكسفرين أجار - بينما كان المتوسط اللوغاريتمى بالفحص الكمى باستخدام البيل أجارسان بريلينت جرين المعدلة كالآتى 2.15

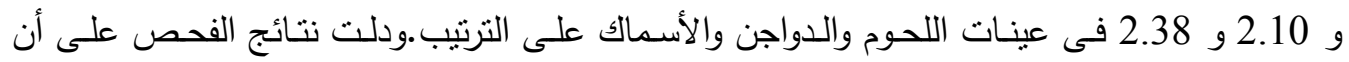
استخدام البيل أجارسان بريلينت جرين أجار المعدلة أكثر دقة فى عد ميكروب الألئ الأيروموناس من استخدام

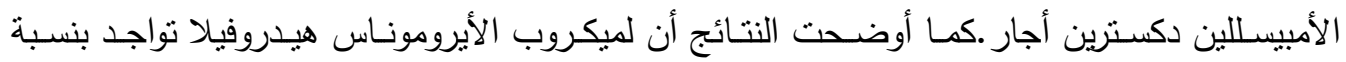

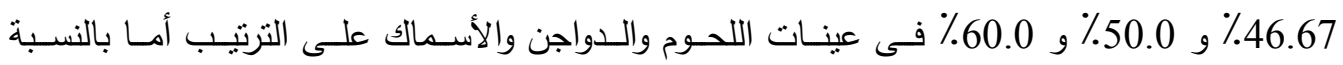

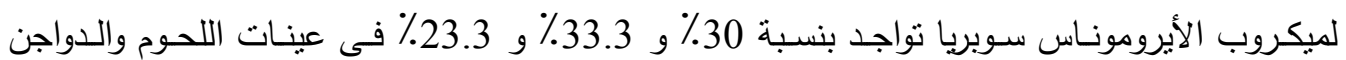

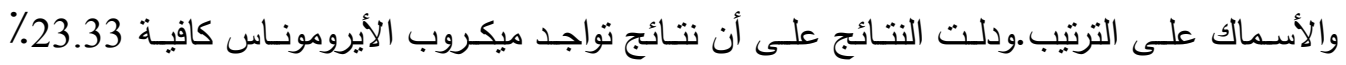

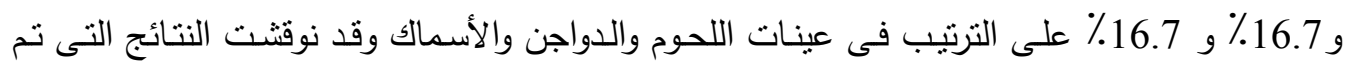

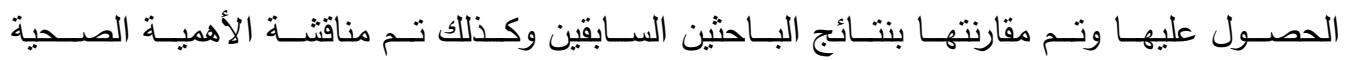

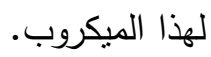

